walls of the hall which was to be heated, and it was found are nocturnal in their habits, and are often surprised by the 4 th. The number of rigs erected and being erected at the that just as the heated air entered from the stove room so natives in the act of making a raid upon the sweet potato close of the month exceeds that of any previous month.

the mercury in the several thermometers rose, whether they patches, and captured by throwing sticks at their legs or 5th. The amount of crude produced in the month was were hung on the same wall in which was the opening to caught in nooses; in the latter case they frequently the stove room, or on the north wall, fifty feet away. by feigning death.

\section{THE KANCHIL, OR PYGMY MOSK.}

\begin{tabular}{c|l}
\hline THE KANCHIL, OR PYGMY MUSK. & $\begin{array}{l}\text { mestic pets. It is of this species that a rather doubtful story } \\
\text { BS DANTEL C. BEARD. }\end{array}$
\end{tabular} Last winter while we New Yorkers were bringing into they will leap into the overhanging branches of somefriendly requisition all modern appliances within our reach to ward off tree, and hang suspended by their large canine teeth until the the cold waves that came rolling over us from the mountains too eager foe rushes by, thendropping to the ground they and plains of solid ice of the northern frozen regions, while will calmly retrace their steps. It is said that the creatures our ears and nose, our fingers and toes, were tingling in the can make most extraordinary leaps, and that they display frosty air of midwinter, the crew of the good ship Janet great cunning. They have no musk bag, and like the rest Furguson were sweltering under the burning rays of a tropi- of the family are destitute of horns. The antlers we see upon cal sun. The ship was on her return trip from Singapore to stuffed specimens in the windows of the taxidermist are artiNew York with a cargo of pepper and spices. When pass- ficial.

ing through the Straits of Sunda she was met and surrounded The doe in my possession measured 15 inches in length, ing through the Straits of Sunda she was met and surrounded
by the usual flect of native bum boats laden with fruits and
the head rather large, being $4 \frac{1}{2}$ inches from point behind the curiosities. Among the miscellaneous cargo of these sea ears to tip of its nose; nose movable, always wet and cold peddlers' boats one had aboard some of the most graceful, like a pointer dog, and like that dog she possessed a keen
beautiful little creatures one could well imagine-five full
scent. The round, short ears gave the animal the appearance grown live deer, not larger than small rabbits. The captain of a mouse. The canine teeth were short, slender, and sharp, of our Janet Furguson after some parley succeeded in pur- and, unlike the buck's, did not extend below the lips. The ten chasing them, giving in exchange an old silver watch. The inch mark upon the rule came above the highest part of her of the business.

6th. The amount of stock in the producnig resion exceeds the amount ever before held.

7th. The shipments out of the region were larger rhan in y corresponding month in the past.

8th. The price of crude at the wells ruled lower than in ny corresponding month since 1862 .

The annual report of the Chief of the Bureau of Statistics commerce and navigation for the fiscal year ended Junc tracts:

A larger percentage of the mineral oil product of the couritry is exported than of any other product, except cotton. Petroleum ranks fifth in value among the exports of the United States, as shown by the following statement of the five principal commodities exported during the tiscal year ended June 30, 1878

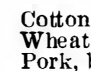

Pork, bacon, hams, and lar
Indian

Indian corn. .......................

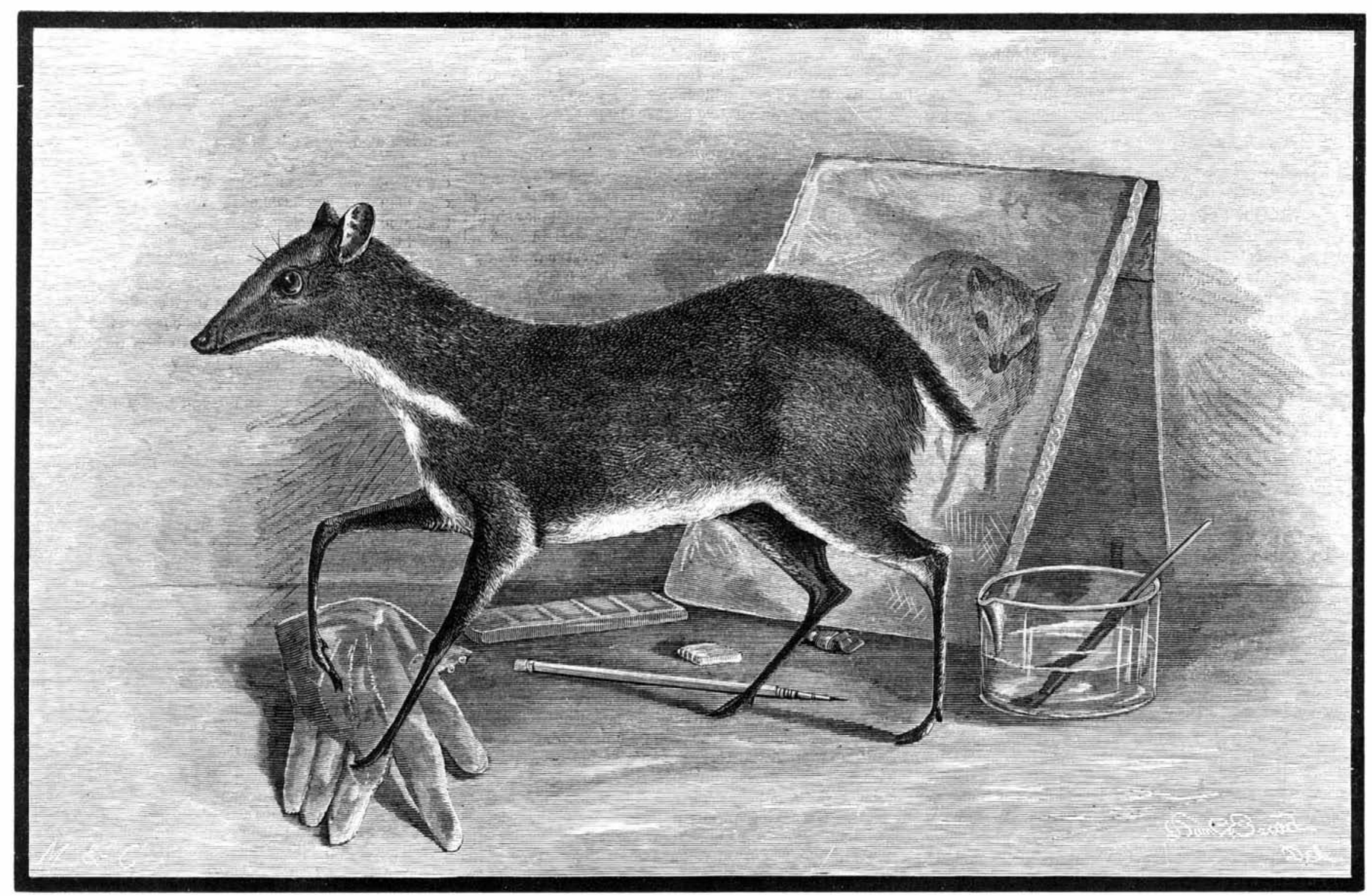

THE KANCHIL, OR PYGMY MUSK.-(Tragulus Pygmwus.)

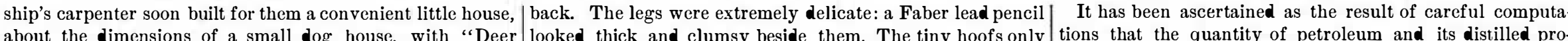
about the dimensions of a small ag house, with "Deer looke thick and clumsy beside them. The tiny hoofs only Lodge " neatly paind of able quarters the little midgets made in safety a voyage of the cloven parts united. The color is a general reddish brown, 136 days, becoming great favorites with the crew. One fawn darker upon the back, where the hairs are tipped with black; was born during the trip, but when discovered by the mate an indistinct dark band runs from a point between the ears -f the vessel the buck had eaten off its legs and it was dead. to nose; rather stiff gray hairs upon the sides and back of Arriving off Sandy Hook the Janet Furguson encountered neck; fawn colored sides; three white streaks under part of a cold wintry gale, all hands were kept busy, and during the neck; soft white hair upon belly and the anterior upper part confusion three of the little creatires that had manared to es- of hind legs and the posterior upper part of fore limbs; the confusion the ge the little creatures that had manage to escape from their snug little house perishe with the cold fell a victim to our (to them) inhospitable climate. The only survivor, a beautiful doe, represented in the above drawing, survivor, a beautiful doe, represented in the above drawing,
came into my possession; but she only lived about a week came into my possession; but she only lived about a week. In spite of all my care she too expired, killed by the cold breath of our New York winter.

She was a titnid little creature, and although perfectly tame objected to being handled, but she would take food from my hand and allow me to stroke her back. She had the pose and action of our ordinary deer. When watching her ase leaped over a footstool, or stood, lead erect, with one fore foot gracefully poised, in an eager, listening attitude, or crept timidly and stealthily close to the wall and behind the crept timidly and stealthily close to the wall and behind the articles of furniture, it was as difficult to realize that it was
a real live deer as it is to believe that the midget General Mite is actually a living specimen of the genus homo.

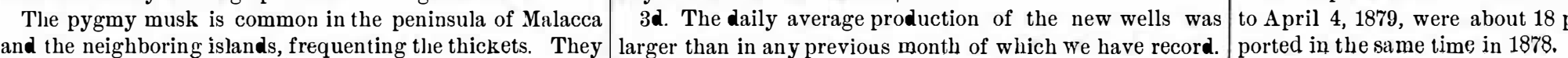
of hind legs and the poste

These animals could in all probability be acclimated in our Southern States, especially in Florida, abounding as that State in swamps and thickets, where the animals could ecure coverts and breed.

\title{
Progress of Petroleum.
} Pennsylvania for the month of March is, says Stowell's of $P$ United States from January 1, 1879, to April 4, 59,756,732 troleum Reporter, certainly surprising, to use a very mild ex 1879, 9,125,988 gallons.

pression. They reveal a state of affairs that have never be- The daily average production for the month of March, 1879, fore existed in the oil regions, and we think gives very little was 47,615 barrels, againist 38,980 barrels for March, 1878 , hope for the immediate future. The following facts appear: which is an increase of 8,635 barrels, or about 22 per cent, 1st. That there were more wells drilling at the close of the to which add $9 \cdot 4$ per cent produced in 1878 more than was month than in any corresponding month since 1870 .

2d. More wells were completed during the month than in ny month since November, 1878 nth than in $\begin{gathered}\text { crease of about } 31.4 \text { per cent in production to be provided for. } \\ \text { The exports trom the United States from January 1, 1879, }\end{gathered}$ needed for the export and home trades, and we have an in 


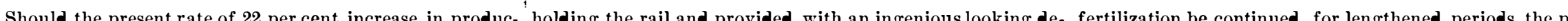

Should the present rate of 22 per cent increase in produc-
tion be kept through the tion be kept through the year, which it now bids fair to do, and the present rate of 18 per cent increase in exports main tained, we will have at the close of 1879 an overwhelming
amount of stock on hand, except new markets shall be found, which will increase the export demands; or new uses, which will increase the home trade.

The number of producing wells at the close of March, 1879, The number of producing wells at the close of March, 187 ,
was 10,692. The number of drilling wells completed in was 10,692. The number of drilling wells completed in
March was 338 . Total production in March, $1,476,065$ barrels; the average daily production of the new wells in March was

for the month was $41-10$ barrels.

The stock in the producing regions has been increased during the month, 502,186 barrels, making the total stock at the companies, tankers, and operators.

\section{RECENT MECHANICAL INVENTIONS.}

An improved washing machine, which does its work principally by pressure upon the clothes, has been patented by Mr. Charles P. Rood, of La Fargeville, N. Y. The machine consists of a tub having a number of deep transverse ribs in
the bottom, and a fluted roller carried back and forth over the bottom by a carriage worked by a rack and pinion.

An improved clothes pounder, which acts by forcing air through the clothes, has been patented by Mr. C. F. K. Wilson, of Seymour, Io

without rubbing.

An improved animal trap, which is designed to be set ove a barrel set in the ground and partly filled with water, has been patented by Messrs. N. H. Williams and L. Chapman of Murrayville, Ill. The trap readjusts itself after having caught an animal.

Mr. Peter H. Baker, of San Francisco, Cal., has patented an improved door latch, which may be used simply as a latch or it may be locked with a key, which will prevent the withdrawing of the latch.

An improved hand truck, in which the bearer bars, to which the axle is bolted, and the backguard are made in one piece and bolted to the inner flanges of angle iron side bars, piece and bolted to the inner flanges of angle iron side bars, has becn patented by Mr. Thomas Hill, of Jersey City, N. J.
Mr. Frederick Hollick, of New York city, has patented an Mr. Frederick Hollick, of New York city, has patented an
improved vehicle wheel, having a flanged tire and fellies pro-

vided with radial spokes, which are secur
hub in a novel and substantial manner.

An improved guide for harness makers' sewing machines, which enables the machine to be used in sewing up seams in round lines, has been

An improved press, for baling cotton and other similar materials, has been patented by Mr. E. F. McGowen, of Housterials, has been patented by Mr. E. F. McGowen, of Hous-
ton, Texas. This invention consists in a novel arrangement ton, Texas. This invention consists in a novel arrangement
of gearing for operating the press without changing the motion of the driving shaft.

Messrs. D. W. and H. Johns and Henry Embs, of New Albany, Ind., have patented an improved machine for making ox-polls. In this machine the ox-polls are made by the rolling process, the iron bar being first bent into a $\mathrm{V}$-shape and the eye formed; the ends or flanges are then

Messrs. C. H. Lane, W. A. Hutchins, and John McGrew, of Garnettsville, Ky., have devised an improved washing machine, which consists of two hollow cylinders provided machine, which consists of two hollow cylinders provided
with longitudinal ribs and arranged to rotate in contact with each other.

An improved machine for operating a clothes pounder or churn dasher has been patented by Mr. P. C. McCune, of Mount Etna. A revolving platform supports the tub or churn, and a reciprocating
dasher, as may be required.

An improved carriage wrench, which consists essentially of a socket wrench divided longitudinally, the two parts being jointed together and provided with adjusting screw

been patented by Mr. E. A. Robbins, of Fairfield, Me.

Mr. Abner Hart, of Ogden, Ill., has devised an improved
washing machine, which is provided with recessed pounders washing machine, which is provided with recessed pounde
having air pumps attached, and with foot levers in conne tion with hand levers for operating the pounders.

An improved machine for operating a churn, turning grindstone, sawing wood, and for other applications where a Drake, of Horseheads, N. Y. The invention consists in novel arrangement of a weight and gearing.

Mr. Charles B. Hill, of Nashville, Tenn., has patented an improvement in middlings purifiers. This machine, which improvement in middlings purifiers. This machine, which
seems simple and effective, cannot be described without diagrams.

Mr. John B. Overmeyer, of New Lexington, O., has devised an improvement in time locks, which is so arranged
that in case the watch movements which control the main bolt should stop the lock may still be opened from the out side at a certain fixed time.

An improvement in vehicle axles, patented by Messrs (Mertawn P O) Pa and Peter W. Wertz, of Longswamp for securing the axle spindle to the axle.

An improved heat regulator, patented by Mr. E. S. Gary of Baltimore, Md., is operated by the expansion and contraction of a fluid acting on a piston connected with the damper of a stove or furnace.

Mr. Henry Reese, of Baltimore, Md., has patented an im- works have gone too far to strengthen the belief that interproved wrought iron railway tie, having upturned lugs for $!$ crossing is absolutely necessary for plants, and that if self- ice for preventing the displacement of the rail.
A novel mechanical movement for converting motion
ither for an increase of power or speed has been patented ither for an increase of power or speed has
y Mr. Theodore Scholze, of Angola, Ind.

\section{Cast Steel Armor for Ships.}

The material of which thick armor should be made, say Mr. Barnaby, is now the subject of anxious experiment in
Germany and France, as well as in Italy and England. Stee nd other alloys of iron are so little known or understood, that there is a large field for experiment open for the armor plate maker and for the artillerist. Steel has been tried many times alone, and in combination with iron, but it neve
gave enough satisfaction to secure its adoption until experiments were made at Spezzia with plates 55 centimeters thick, manufactured by Schneider \& Co., at Creuzot. With these the Italian Government were so well pleased that they are plating the Dandolo and Duilio with such plates. Those of us who visited the French Exhibition last year may have
seen a steel armor plate produced by this firm, bent to the seen a steel armor plate produced by this firm, bent to the
form of a turret, 32 inches thick, and weighing 65 tons. Those who went to the works at Creuzot, by favor of Mons.
Schneider, may also have seen an ingot of cast steel, suitable for making an armor plate, and weighing 120 tons. The rival firm of Terre Noire exhibited armor plates of steel which had not been hammered, or rolled, or otherwise forged.
They were simply cast plates, tempered in oil, and annealed. Judging from the admirable series of specimens and tests and analyses, the manufacture has already attained a large degree of precision, aud is full of promise. I believe that the Italian Government will shortly test some of it with the
big Elswick gun, and it may be that blocks of cast steel will evolutionize the manufacture of armor by making the rolling operations unnecessary, and bringing down the cost to that of ordinary large castings. The French Government Havre, but have mot yet satisfied themselves that they should give up wrought iron. Experiments with steel in England ave shown that steel can be made of great hardness, so ard that it will break up all projectiles which strike it, and
that will not suffer seriously in doing so. Sir Joseph Whit orth has obtained some most remarkable results in this direction, and he is still pursuing the inquiry.

\section{NATURAL HISTORY NOTES.}

Winter Habits of the Eel.-It is well known that the eel will, of its own accord, leave a pond or stream and wander Abbott, in the Science Neros, usually when the hot summer's un has evaporated the water of the pond in which the fish happens to be, or so lessened its bulk that the eel finds the
ocality no longer suited to its wants. In such a case the cality no longer suited to its wants. In such a case the
animals leave the stagnating waters of a land-locked pond and, with a serpent-like motion, pass through grass well wetted with dews or showers. They seem to exhibit a sense of ditream. These land migrations are more frequent during venings, when a heavy dew is deposited, than at other times. In watching the progress of the work in clearing a piece of
meadow land on March 8th, Dr. Abbott was surprised to find in a mossy mass of earth and ronts, through which water rom a neighboringspring circulated (though not in sufficien quantity to enable any fish to swim in it), a group of eels,
seventeen in number. They were not in a tangled mass, so intermingled as to suggest that they sought contact for mutual warmth, but each was coiled in a snake-like manner
by itself. On taking them up they seemed sluggish, and made no effort to escape until revived by the warmth of the writer's hand, when they struggled to get free. When given est point at which they could reach the ditch hard by. Two
Twe of the fishes were dissected, and the amount of matter in their stomach was so small that Dr. Abbott believes that they had been fasting during their semi-aquatic sojourn in the place where they were detected. Subsequent close examination of the spot showe that the spring water did not, and had
not, run as a stream through it. There was every indication that these eels had voluntarily left the ditch, fifty feet distant, nd sought out this spring hole, which from its southern exposure and constant supply from the spring was a comfortable spot. The question arises: is this a common occurrence, bottoms of our deeper ponds and the tidal portions of our vers?

A Green Spored Toadstool.-As well known to botanists the eries, according to the color of the spores. These series are: the white spored (Leucospori), pink spored (Hyporhodii), brown
spored (Dermini), purple spored (Pratelle), and black spored (Coprinarii). Hitherto no species of toadstool belonging to the several genera into which the order is divided has been
known to occur with mature spores of any other color than some shade of those above noted Recently Mr. C. H. Peck
has detected a species of Agaric with green spores. Unti some other species shall occur with spores of this color he is dispo to assign this anomalous specimen to a place among
he white spored species, to which in structure it appears to be related. hat inter- because tumbling about in a gale he would be a more dan
at if self. $\mid$ gerous object than the loose gun told of by Victor Hugo.

tend to degenerate and thence to ultimate extinction. This he believes to be absolutely false. In an article in the Pop ular Science Review he gives the following conclusions: 1 . selves. 2. Very few plants are known to be physiologically
s. self-sterile when the pollen of a flower is placed on the stigma of the same flower. 3. Several plants are known to be morhologically self-sterile, in that the pollen cann ot, without id, reach the stigma, but is effective on that of the same ower. 4. Self-sterile plants from both the above causes can become self-fertile. 5. Highly self-fertile forms may arise
under cultivation. 6. Special adaptations occur for selfunder cultiv

The "Digger" Mollusk and its Parasite.-The pretty little hellish, the "digger" (Donax fossor), not uncommon on our ew Y York coast, represents a countless mass of life off Cape May, New Jersey, large areas looking like barley grains lying on a malting floor when the tide retires. The mollusk gets uncovered by the breaking surf and immediately reburies
itself with its powerful foot when the waves retire. The siphons are long and active, looking like so many wriggling worms. Although the prey of shore birds and fishes, and beset with parasites, they lie so thickly as even to interfere with valves is always found beset by flukes, from half a dozen to several dozen, and a bell-shaped trichodina crowds the nchial cavity.

The May-bug in Europe.-The grub of the May-bug or May beetle (common to Europe and America) is perhaps,
with the exception of the phylloxera the most destructive pest the French husbandman has to contend against. recent sitting of the Central Horticultural Society, of Paris, it was stated by the head gardener at Chantilly that they ways' estroying the roses. One hundred and eighty-seven days' labor were expended upon about an acre of ground,
each man disabling 5,000 of these insidious grubs daily, the total amounting to close upon a million. Another member
torious a stated that he had had upward of half a million collected on very hectare of his estate.

These beetles, according to old accounts, were at one time as great a plague in England as the locust is in America. A ary 24, 1574, there fell such a multitude of these insects into the river Severn that they clogged and stopped the water wheels. Further, we are told in the Transactions of the kingdom suffered so greatly by the devastations made by kingdom suffered so greatly by the devastations made by
these insects that they set fire to a wood some miles in length, whese insects that they set fire to a wood some miles in length,
which parted two adjacent counties, to prevent them dispersing themselves any further that way.

The Age of Seeds and the Sex: of Flowers. - At a meeting of he Botanical Society of France, M. Duchartre called attention culan Horticultural Society, in 1877, to the effect that melon raised from fresh seed bear a large proportion of male flowers and very few female flowers; while, on the other hand, seedand very few female flowers; while, on the other hand, seed-
lings raised from old seed bear many more female flowers lings raised from old seed bear many more female flowers
than male. The statement was confirmed by M. Millet, a than male. The statement was confirmed by M. Millet, a
French grower; and, it may be added, by the experience and practice of gardeners in England (on the authority of the Gardeners' Chronicle).

Should the English Sparrow be Protected?-These birds, wich have now proved such a nuisance in America, seem those few persons who were instrumental in introducing them. The English them-
selves warned us against the pest. Not long ago a great outelves warned us against the pest. Not long ago a great out-
cry was raised against them by the farmers in Algeria, and

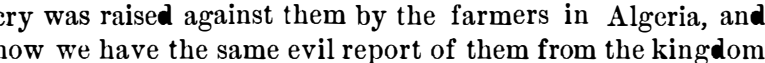
now we have the same evil report of them from the kingdom
of Saxony. A recent English paper says that "the Council of Agriculture of the latter country has decided to petition he government to repeal the law which makes it an offence to destroy them. Indeed the feeling against sparrows has cided to destroy them in defiance of the law. It is asserted that a microscopical examination of their crops proves that parrows live upon grain during eight or nine months of the ear, and are only insectivorous when reduced to it by necesity. It is the same cry from far and near, from America and Australia, where the 'dissolute, unmusical rover' has
been introduced and protected by stringent enactments, in return for which he was expected to eat a great many insects and very little else."

The Effect of a Sea Voyage on Animals.-Most of the wild nimals procured for the menageries and zoological garden f Europe and America are brought from Africa via North Germany by Mr. Reiche, the proprietor of the New York Aquarium. They are brought from Africa (mainly as cubs) to Trieste and thence to North Germany, and from there they are distributed to countries where they are wanted. These animals are usually brought to the United States by the North German steamers, and it is interesting to learn about
heir habits on shipboard. Charles Reade. the novelist, always inaccurate when he goes out of his way as a writer of fiction to dip into science, has stated that the sagacious elehant in storms at sea saves himself from being washed off heck by throwing himself flat upon his belly, with ex tended legs and trunk outspread with suction power upon the planks. Captain Nevnaber, however, says that no ship beause tumbling about in a gale he would be a more dan 